\title{
Bio-preservation of processed watermelon (Citrullus lanatus) juice using Lactobacillus species isolated from processed fermented maize (akamu).
}

\author{
Ike Christian Chukwuemeka ${ }^{1,}{ }^{*}$, Ogwuegbu Happiness Odinakachi ${ }^{2}$ and Akwari Dike Kalu ${ }^{1}$ \\ ${ }^{1}$ Department of Biological Sciences (Microbiology Programme), College of Basic and Applied Sciences, Rhema University, \\ Nigeria, P.M.B. 7021 Aba, Abia State. \\ 2 Department of Microbiology, Abia State University Uturu, P.M.B. 2000 Uturu, Abia State. Nigeria.
}

Publication history: Received on 23 February 2020; revised on 06 March 2020; accepted on 17 March 2020

Article DOI: https://doi.org/10.30574/gscbps.2020.10.3.0047

\begin{abstract}
Bio-preservation of processed watermelon (Citrullus lanatus) juice using Lactobacillus species isolated from processed fermented maize (akamu) was conducted using standard methods for shelf life study. Two Lactobacillus isolates designated $\mathrm{L}_{1}$ and $\mathrm{L}_{2}$ isolated from processed fermented maize (akamu) and identified as Lactobacillus fermentum and Lactobacillus brevis were used in the treatment. Three (3) different designates for inoculum volumes and species: $\mathrm{L}_{1} \mathrm{~T}_{1} / \mathrm{L}_{2} \mathrm{~T}_{1}, \mathrm{~L}_{1} \mathrm{~T}_{2} / \mathrm{L}_{2} \mathrm{~T}_{2}, \mathrm{~L}_{1} \mathrm{~T}_{3} / \mathrm{L}_{2} \mathrm{~T}_{3}$ were used for inoculated watermelon samples and the un-inoculated ( $\left.\mathrm{T}_{0}\right)$ was used as control. All were stored at ambient temperature and monitored for shelf life study for seven days. The bacterial count (CFU/mL) ranged from $1.8 \times 10^{5} \pm 0.08$ to $5.9 \times 10^{5} \pm 0.45$, while fungal count ranged from $0.9 \times 10^{3} \pm 0.90$ to $4.7 \times 10^{3}$ \pm 0.32 . Reduced $\mathrm{pH}$ and increased acidity values were observed in the inoculated juice samples than in the un-inoculated samples. Sample $\mathrm{L}_{1} \mathrm{~T}_{3}$ had the best shelf life study parameters followed by $\mathrm{L}_{2} \mathrm{~T}_{3}$ and $\mathrm{T}_{0}$ as the least. Therefore, this study has shown that treated watermelon juice samples with Lactobacillus species isolated from fermented maize (akamu) could produce antimicrobial or organic compounds that are capable of stemming the problem of spoilage, retaining the organoleptic properties of the processed juice and eventually extending the shelf life of the preserved juice, ensuring non seasonal availability of watermelon juice possible.
\end{abstract}

Keywords: Bio-preservation; Watermelon; Food safety; Shelf life; Lactic acid bacteria (LAB).

\section{Introduction}

Watermelon is a warm-season crop that is grown worldwide, usually in the regions with long warm growing season. Citrullus lanatus (watermelon) is a fruit of about $93 \%$ water, hence the name "water" melon. The "melon" part came as a result of its large, round and sweet pulpy flesh [1] that is high in moisture content [2] and which made it highly susceptible to microbial spoilage caused by gram positive bacteria which are very sensitive to low acidity [3].

Juices are the aqueous liquids extracted usually from one or more fruits [4]. Juices are prepared mechanically by squeezing or macerating the pulp of fresh fruits or vegetables without application of heat or solvent to give an unfermented clouded and untreated juice ready for consumption. The traditional method of preparation of juice exposes the juice to microbial contamination through various means [5].Watermelon is rich in vitamin $C$, vitamin $A$, vitamin $B$, amino acid and also carotenoid lycopene. The red flesh of watermelon contains some vitamin A [6]. Watermelon is rich in vitamin $B$ that is primarily responsible for the production of energy in the body. Vitamin $C$ has been found as essential nutrient for humans because it aids in the synthesis of collagen inaddition to protecting against oxidative damage, it has also shown to protect against stomach, oral, and lung cancers, prevent scurvy and improve cholesterol [7; 8].

\footnotetext{
${ }^{*}$ Corresponding author: Ike Christian Chukwuemeka
} 
Lactic acid bacteria (LAB) are gram-positive microorganisms, prefer anaerobic conditions but are aero-tolerant, catalase negative, cocci or rods. These groups of bacteria are non-pathogenic, produce organic acids during the fermentation of carbohydrates. LABs are divided into two groups depending on their fermentation pathway. Homofermentative bacteria such as Lactococcus and Streptococcus yield two lactates from one glucose molecule. Heterofermentative such as Leuconostoc and Weissella produce one lactate, ethanol and carbon dioxide out of one glucose molecule. In addition, LAB produces small organic compounds that give the aroma and flavor to fermented products. $\mathrm{LAB}$ contribute to enrichment of the human dietary through development of a wide diversity of flavors, aromas and textures in food through the fermentation process and, enrichment of food substrates biologically with protein, essential amino acids, essential fatty acids and vitamin [9].

Lactic acid bacteria has a long history of use as bio-preservatives for food and feed storage; they are known to produce different antimicrobial compounds that are able to control pathogenic, spoilage bacteria, undesirable spoilage yeast and spoilage mold [10;11]. Their preserving effectmainly relates to production of organic acidsuch as lactic acid and acetic acid, hydrogenperoxide, diacethyl, production of bacteriocins and protein, or proteinaceouscompounds [11;12].

Bio-preservation refers to extended storage life and enhanced safety of foods using the natural microflora and (or) their antibacterial products. It can be defined as the extension of shelf life and food safety by the use of natural or controlled microbiota and/or their antimicrobial compounds [13]. One of the most common forms of food bio-preservation is fermentation, a process based on the growth of microorganisms in foods, whether natural or added. It employs the breakdown of complex compounds, production of acids and alcohols, synthesis of Vitamin-B12, riboflavin and Vitamin$\mathrm{C}$ precursor, ensures antifungal activity and improvement of organoleptic qualities such as, production of flavor and aroma compounds. The organisms involved mainly comprise lactic acid bacteria, which produce organic acids and other compounds that, in addition to antimicrobial properties, also confer unique flavours and textures to food products. Compounds such as organic acids, bacteriocins, diacetyl and acetaldehyde, enzymes, $\mathrm{CO}_{2}$, hydrogen peroxide etc. contributes to antimicrobial activity by microbiota [13; 14]. The need to incorporate novel and effective combinations has spurred interest for natural and biological preservatives such as lactic acid bacteria and their antimicrobial compounds. This study was to evaluate potential use of some species of Lactobacillus as bio-preservative agents in watermelon juice.

\section{Material and methods}

\subsection{Sample purchase and transportation}

The fermented maize (Akamu) for Lactobacilli isolation and a fresh matured watermelon fruits for juice extraction were purchased from a local market (Relief Market) in Owerri. Samples were transported in ice bags to Microbiology Laboratory, Rhema University, Nigeria.

\subsection{Isolation of Lactobacillus species}

The fermented maize (akamu) sample was prepared by serially diluting $1 \mathrm{~g}$ of it in sterile distilled water in a test tube from first dilution $\left(10^{-1}\right)$ to the fourth dilution $\left(10^{-4}\right)$. The inocula were collected from the second $\left(10^{-2}\right)$ and fourth $\left(10^{-}\right.$ ${ }^{4}$ ) dilutions of the fermented maize and were inoculated on sterilized de Mann, Rogosa and Sharpe (MRS) agar plates [15] as described by the manufacturer (Oxiod). The plates were incubated at $37^{\circ} \mathrm{C}$ for $24-48$ hours and observed daily for growth. The incorporation of $0.02 \%$ sodium azide into the MRS agar made it selective for lactic acid bacteria.

On establishment of growth, each plate was examined for the presence of distinct colonies. Such colonies were collected aseptically and sub-cultured using the streaking technique [16] on fresh MRS agar plates and incubated at $37{ }^{\circ} \mathrm{C}$ for 24 hours. The presence of discrete colonies in the sub-cultured plates showed purity of culture. Isolates from the culture were used for characterization and subsequent identification.

\subsection{Identification of Lactobacillus isolates}

Identification of the Lactobacillus isolates was based on corresponding characteristic of the isolates as recorded in the characterization and identification tests, as contained in Standard Manuals including Bergy's Manual of Systematic Bacteriology [17] and conventional microbiological methods according to [18]. The recorded features obtained from test results of each isolate were matched with existing information in the manuals, and probable organism with corresponding features was identified accordingly, and stored in sterile agar slant bottles for further use. 


\subsection{Production of watermelon juice}

A healthy watermelon fruit with unbroken skin was used. The fruit was washed with clean water and rinsed with distilled water. It was surface disinfected with $70 \% \mathrm{v} / \mathrm{v}$ ethanol solution and was carefully cut open with a sterilized kitchen knife. The flesh (pulp) was scooped into a blender, and was blended with distilled water to make 1:1 (w/v) mixture. The homogenized blend was sieved through a two-fold muslin cloth to obtain the juice used in the study [19].

\subsection{Treatment of juice with Lactobacillus}

The identified Lactobacillus in slant was activated by culturing a loopful of inoculum in 10mls of sterile MRS broth for 24-48 hours. The broth culture was diluted in sterile distilled water to a turbidity matching one half of McFarland standard. Each of the two identified Lactobacillus species was inoculated into the watermelon juice at three different concentrations, and an untreated watermelon juice was used as control. The watermelon juice was inoculated with 0.5 $\mathrm{mL}, 1.0 \mathrm{~mL}$ and $2.0 \mathrm{~mL}$ of the Lactobacillus inoculum per liter of juice. All the treated juice samples were allowed to stand on the shelf at ambient temperature while analyses were carried out on daily basis until spoilage was observed. To prevent contamination, the treated juice were kept in $200 \mathrm{~mL}$ clean-sterile storage plastic bottles (10 bottles for each treatment concentration) and one bottle was collected for analysis each day such that there was no tampering of stored containers during the period.

\subsection{Shelf life studies}

The physicochemical properties of the processed juice were analyzed using standard methods of [20] to determine its baseline quality characteristics and attributes which covered some nutritional qualities and sensory evaluations. The following attributes were used for the different quality determination: $\mathrm{pH}$, total titratable acidity (TTA), total solid and sensory evaluation. Microbial load was also conducted both on the freshly processed juice and the stored juice samples. All analyses were repeated daily, until spoilage was observed.

\subsection{Sensory quality profile}

Sensory quality was checked using standard Hedonic scale method with trained professionals.

\subsection{Statistical analyses}

All obtained data in this study were analysed using ANOVA. Descriptive statistics in form of means and standard deviation and Duncan post hoc were also used to assess the data. The analyses were done using SPSS 21 to determine the level of differences between the control, treated samples and the different treatments.

\section{Results}

The Lactobacillus species isolated and identified using standard methods from the fermented maize (akamu) were Lactobacillus fermentum as $\mathrm{L}_{1}$ and Lactobacillus brevis as $\mathrm{L}_{2}$. Figure 1 to 7 showed results of the various treatments on the processed watermelon juice during storage. The $\mathrm{pH}$ of stored juice samples ranged from $3.8 \pm 0.33-5.5 \pm 0.04$. The $\mathrm{pH}$ of $\mathrm{T}_{0}$ increased significantly $(\mathrm{p}<0.05)$ as storage days progressed. The lowest $\mathrm{pH}$ of $\mathrm{T}_{0}$ was $5.2 \pm 0.55$ at $\mathrm{D}_{0}$, while the highest $\mathrm{pH}$ value was $5.7 \pm 0.04$ at $\mathrm{D}_{7}$. Unlike samples of $\mathrm{T}_{0}$, there was a significant decrease $(\mathrm{p}<0.05)$ on the $\mathrm{pH}$ values in the treated juice samples as the storage days progressed. The $\mathrm{pH}$ value of treated juice samples ranged from $3.3 \pm 0.29$ - $5.2 \pm 0.16$. The lowest $\mathrm{pH}$ value of $3.3 \pm 0.33$ was recorded at $\mathrm{D}_{7}$ of treated juice sample with $\mathrm{L}_{1} \mathrm{~T}_{3}$. 
Ike et al. / GSC Biological and Pharmaceutical Sciences, 2020, 10(03), 126-136

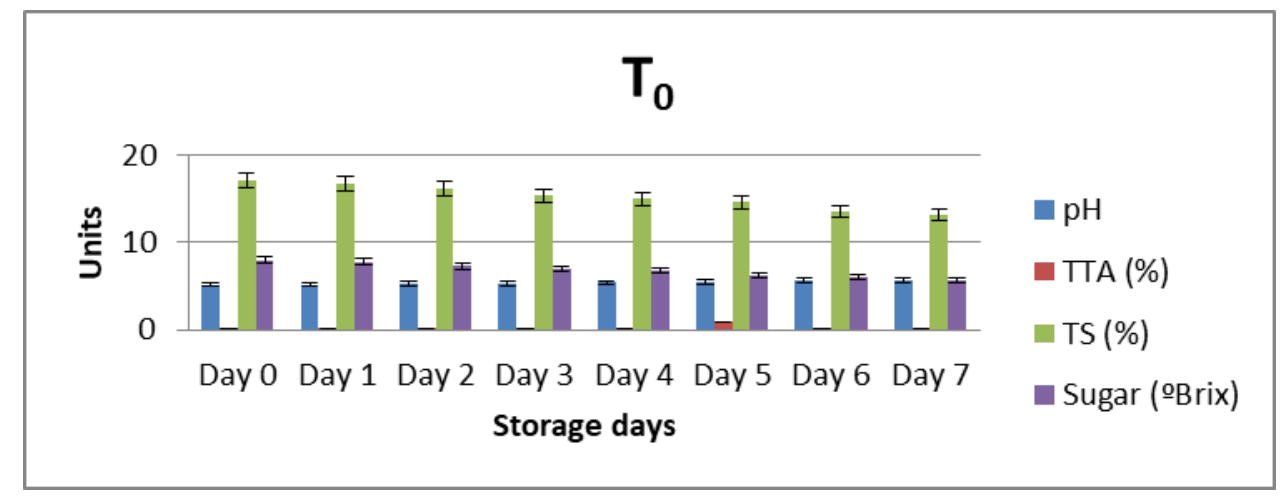

Figure 1. Physicochemical parameters of $\mathrm{T}_{0}$ bio-preserved watermelon juice

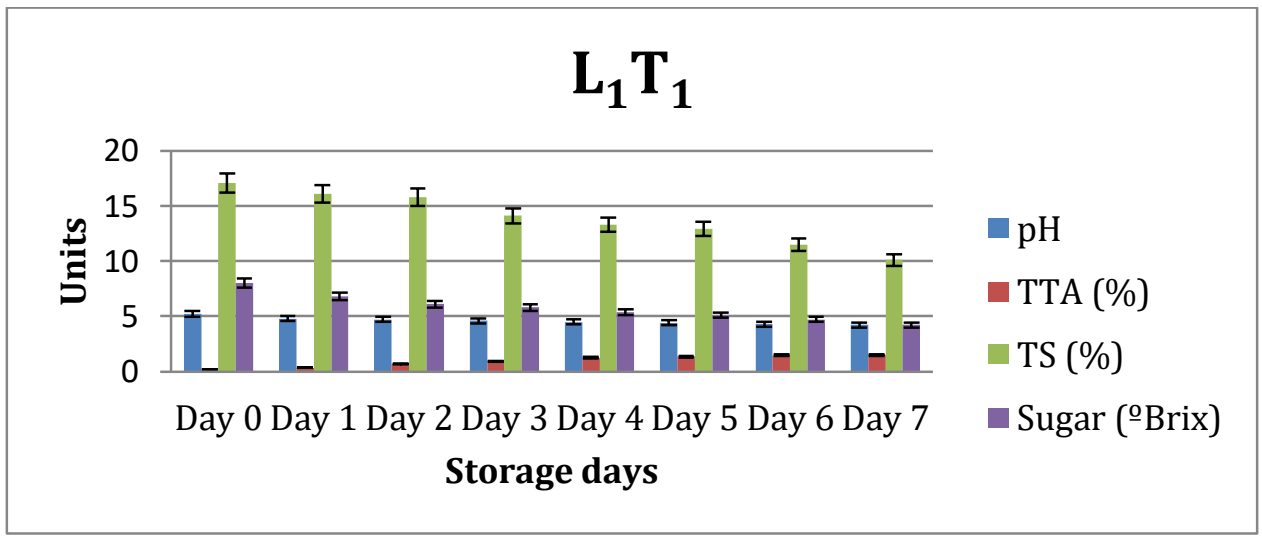

Figure 2. Physicochemical parameters of $\mathrm{L}_{1} \mathrm{~T}_{1}$ bio-preserved watermelon juice

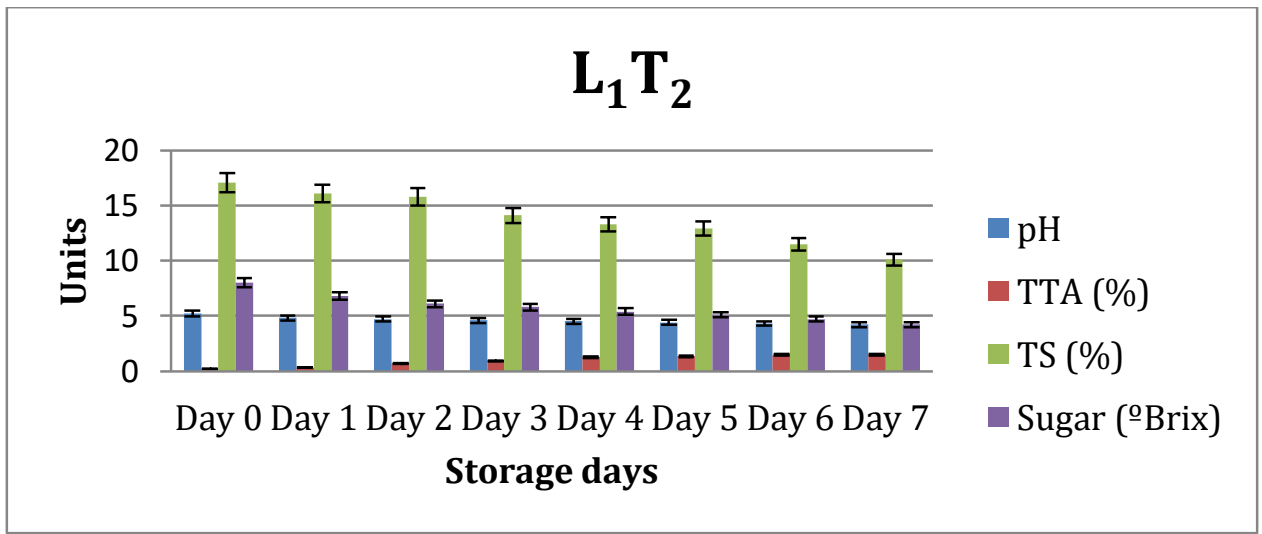

Figure 3. Physicochemical parameters of $\mathrm{L}_{1} \mathrm{~T}_{2}$ bio-preserved watermelon juice 


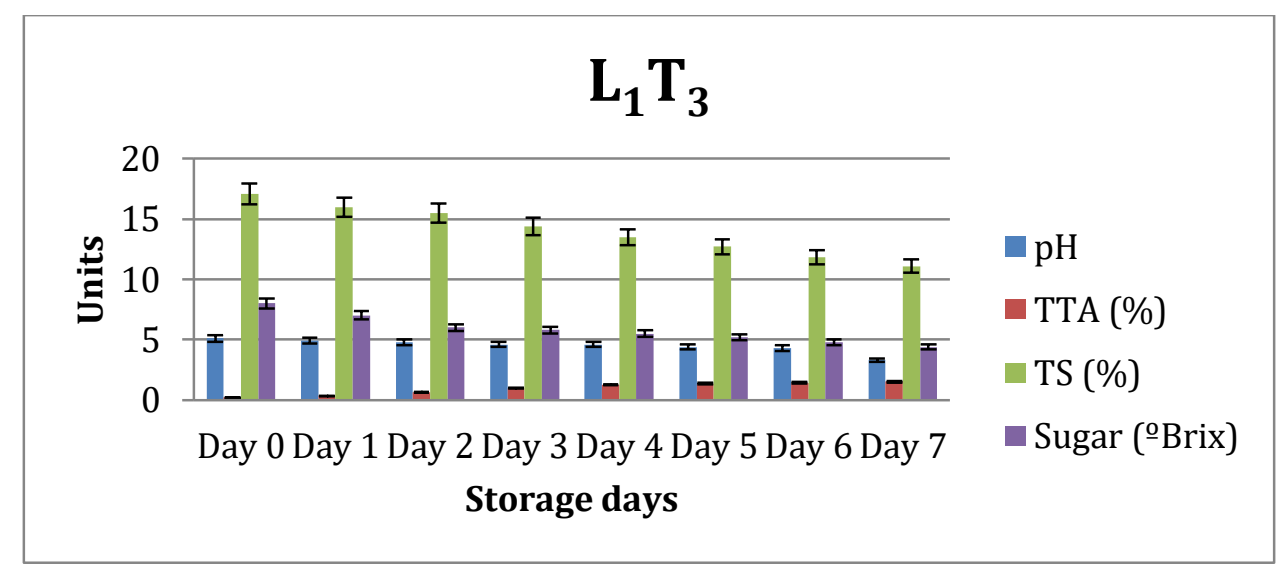

Figure 4. Physicochemical parameters of $\mathrm{L}_{1} \mathrm{~T}_{3}$ bio-preserved watermelon juice

Total titratable acidity (\%) of stored juice sample ranged from $0.06 \pm 0.52-1.66 \pm 0.18$. The lowest total titratable acidity (TTA) value of $0.06 \pm 0.52$ was recorded in $\mathrm{D}_{0}$ of $\mathrm{T}_{0}$ sample, while the highest TTA value of $1.66 \pm 0.18$ was recorded at $\mathrm{D}_{7}$ of treated juice sample with $\mathrm{L}_{1} \mathrm{~T}_{3}$. Total solid (TS \%) value for stored juice samples ranged from 9.8 $\pm 0.10-17.2 \pm 0.06$. The lowest TS value of $9.8 \pm 0.10$ was recorded at $\mathrm{D}_{7}$ of treated juice sample with $\mathrm{L}_{1} \mathrm{~T}_{3}$. Sugar content ( $\left.{ }^{\circ} \mathrm{Brix}\right)$ of the stored juice samples ranged from $3.8 \pm 0.33-8.0 \pm 0.44$. The lowest Sugar value of $3.8 \pm 0.33$ was recorded at $D_{7}$ of treated juice sample with $\mathrm{L}_{1} \mathrm{~T}_{3}$. There was a decrease in total titratable acidity, total solid and sugar content of stored juice samples as storage days progressed. All values obtained during fermentation when compared were statistically significant $(\mathrm{p}<0.05)$.

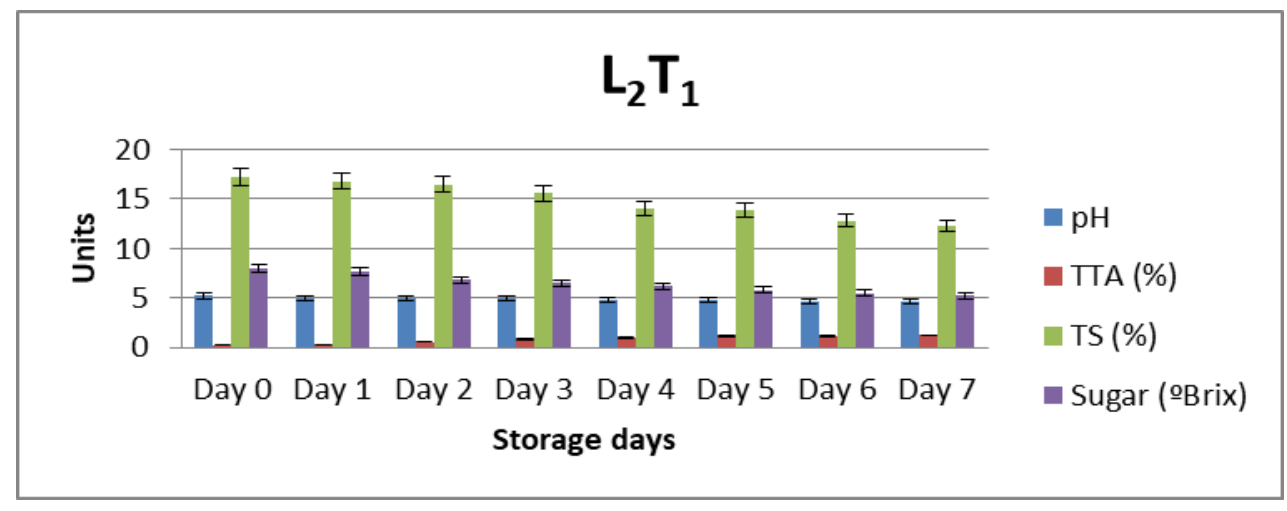

Figure 5. Physicochemical parameters of $\mathrm{L}_{2} \mathrm{~T}_{1}$ bio-preserved watermelon juice

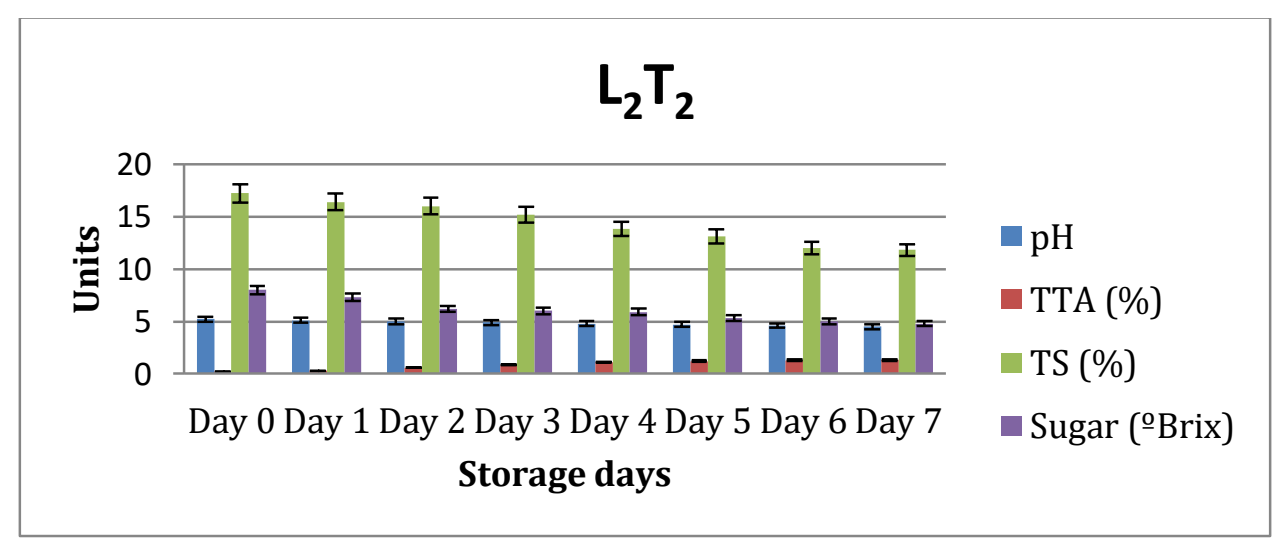

Figure 6. Physicochemical parameters of $\mathrm{L}_{2} \mathrm{~T}_{2}$ bio-preserved watermelon juice 


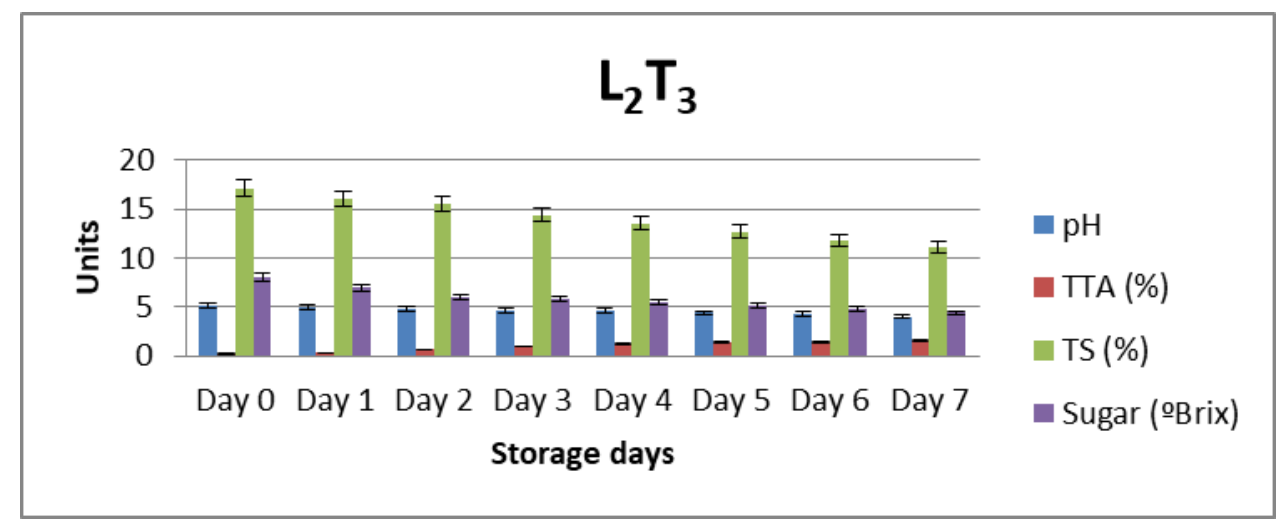

Figure 7. Physicochemical parameters of $\mathrm{L}_{2} \mathrm{~T}_{3}$ bio-preserved watermelon juice

Tables 1 and 2 showed the impact of treatment concentrations on the microbial counts of the stored juice samples. The bacterial load for the stored juice samples ranged from $1.8 \times 10^{5} \pm 0.08 \mathrm{CFU} / \mathrm{mL}-5.9 \times 10^{5} \pm 0.45 \mathrm{CFU} / \mathrm{mL}$, while fungal load for the stored juice samples ranged from $0.9 \times 10^{3} \pm 0.90 \mathrm{CFU} / \mathrm{mL}-5.9 \times 10^{3} \pm 0.88 \mathrm{CFU} / \mathrm{mL}$. The $\mathrm{T}_{0}, \mathrm{~L}_{1} \mathrm{~T}_{1}$ and $\mathrm{L}_{2} \mathrm{~T}_{1}$ had the peak bacterial load of $5.9 \times 10^{5} \pm 0.45 \mathrm{CFU} / \mathrm{mL}, 4.4 \times 10^{5} \pm 0.32 \mathrm{CFU} / \mathrm{mL}$ and $4.6 \times 10^{5} \pm 0.61 \mathrm{CFU} / \mathrm{mL} \mathrm{respectively}$ at $\mathrm{D}_{4}$ storage time, after which there was a progressive decrease as storage days progressed. Unlike bacterial counts, there were no sharp declines in fungal replication at $\mathrm{D}_{4}$ rather what was recorded was a progressive replication par storage days as evidenced in the result. The $\mathrm{T}_{0}, \mathrm{~L}_{1} \mathrm{~T}_{1}$ and $\mathrm{L}_{2} \mathrm{~T}_{1}$ treatments recorded highest fungal load of $5.9 \times 10^{3} \pm 0.88$ $\mathrm{CFU} / \mathrm{mL}, 5.2 \times 10^{3} \pm 0.03 \mathrm{CFU} / \mathrm{mL}$ and $5.3 \times 10^{3} \pm 0.07 \mathrm{CFU} / \mathrm{mL}$ respectively. The juice samples treated with $\mathrm{L}_{1} \mathrm{~T}_{3}$ and $\mathrm{L}_{2} \mathrm{~T}_{3}$ had lowest bacterial load of $1.8 \times 10^{5} \pm 0.08 \mathrm{CFU} / \mathrm{mL}$ at $\mathrm{D}_{1} / 2.0 \times 10^{5} \pm 0.54 \mathrm{CFU} / \mathrm{mL}$ at $\mathrm{D}_{7}$ and $2.0 \times 10^{5} \pm 0.89 \mathrm{CFU} / \mathrm{mL}$ at $\mathrm{D}_{1} / 2.2 \times 10^{5} \pm 0.21 \mathrm{CFU} / \mathrm{mL}$ at $\mathrm{D}_{7}$ respectively. Also, treated juice samples with $\mathrm{L}_{1} \mathrm{~T}_{3}$ and $\mathrm{L}_{2} \mathrm{~T}_{3}$ had lowest fungal load of $0.9 \times 10^{3} \pm 0.90 \mathrm{CFU} / \mathrm{mL}$ at $\mathrm{D}_{1} / 2.0 \times 10^{3} \pm 0.02 \mathrm{CFU} / \mathrm{mL}$ at $\mathrm{D}_{7}$ and $1.0 \times 10^{3} \pm 0.23 \mathrm{CFU} / \mathrm{mL}$ at $\mathrm{D}_{1} / 2.3 \times 10^{3} \pm 0.06 \mathrm{CFU} / \mathrm{mL}$ at $\mathrm{D}_{7}$ respectively. Values obtained in this study with different treatments when compared at different days of fermentation were statistically significant $(\mathrm{p}<0.05)$.

Table 1. Mean bacterial counts (CFU/mL) during storage

\begin{tabular}{|c|c|c|c|c|c|c|c|}
\hline \multirow[b]{2}{*}{ Treatment } & \multicolumn{7}{|c|}{ Storage days } \\
\hline & $\mathbf{D}_{1}$ & $\mathbf{D}_{2}$ & $\mathbf{D}_{3}$ & $\mathbf{D}_{4}$ & $\mathbf{D}_{5}$ & D6 & $\mathbf{D}_{7}$ \\
\hline \multirow[t]{2}{*}{$\mathrm{T}_{0}$} & $3.2 \times 10^{5}$ & $4.0 \times 10^{5}$ & $4.8 \times 10^{5}$ & $5.9 \times 10^{5}$ & $5.1 \times 10^{5}$ & $4.2 \times 10^{5}$ & $3.3 \times 10^{5}$ \\
\hline & $\pm 0.11^{\mathrm{f}}$ & $\pm 0.09 \mathrm{e}$ & $\pm 0.22^{\mathrm{g}}$ & $\pm 0.45^{\mathrm{g}}$ & $\pm 0.33^{\mathrm{g}}$ & $\pm 0.92^{\mathrm{f}}$ & $\pm 0.48^{f}$ \\
\hline \multirow[t]{2}{*}{$\mathrm{L}_{1} \mathrm{~T}_{1}$} & $2.5 \times 10^{5}$ & $2.9 \times 10^{5}$ & $3.4 \times 10^{5}$ & $4.4 \times 10^{5}$ & $4.1 \times 10^{5}$ & $3.5 \times 10^{5}$ & $3.0 \times 10^{5}$ \\
\hline & $\pm 0.66^{\mathrm{d}}$ & $\pm 0.76^{\mathrm{d}}$ & $\pm 0.84 \mathrm{e}^{\mathrm{e}}$ & $\pm 0.32 \mathrm{e}$ & $\pm 0.15^{\mathrm{e}}$ & $\pm 0.19 \mathrm{e}$ & $\pm 0.08^{d}$ \\
\hline \multirow[t]{2}{*}{$\mathrm{L}_{1} \mathrm{~T}_{2}$} & $2.2 \times 10^{5}$ & $2.6 \times 10^{5}$ & $2.9 \times 10^{5}$ & $3.4 \times 10^{5}$ & $3.2 \times 10^{5}$ & $3.0 \times 10^{5}$ & $2.7 \times 10^{5}$ \\
\hline & $\pm 0.07^{c}$ & $\pm 0.54^{c}$ & $\pm 0.76^{c}$ & $\pm 0.54^{c}$ & $\pm 0.42^{\mathrm{c}}$ & $\pm 0.19 \mathrm{c}$ & $\pm 0.68^{c}$ \\
\hline \multirow[t]{2}{*}{$\mathrm{L}_{1} \mathrm{~T}_{3}$} & $1.8 \times 10^{5}$ & $2.0 \times 10^{5}$ & $2.4 \times 10^{5}$ & $2.6 \times 10^{5}$ & $2.5 \times 10^{5}$ & $2.3 \times 10^{5}$ & $2.0 \times 10^{5}$ \\
\hline & $\pm 0.08^{\mathrm{a}}$ & $\pm 0.12^{\mathrm{a}}$ & $\pm 0.67 \mathrm{a}$ & $\pm 0.46^{\mathrm{a}}$ & $\pm 0.55^{\mathrm{a}}$ & $\pm 0.98^{a}$ & $\pm 0.5^{\mathrm{a}}$ \\
\hline \multirow[t]{2}{*}{$\mathrm{L}_{2} \mathrm{~T}_{1}$} & $2.6 \times 10^{5}$ & $2.9 \times 10^{5}$ & $3.5 \times 10^{5}$ & $4.6 \times 10^{5}$ & $4.2 \times 10^{5}$ & $3.5 \times 10^{5}$ & $3.1 \times 10^{5}$ \\
\hline & $\pm 0.44^{\mathrm{de}}$ & $\pm 0.22^{\mathrm{d}}$ & $\pm 0.25^{\mathrm{ef}}$ & $\pm 0.61^{\mathrm{f}}$ & $\pm 0.26^{\mathrm{f}}$ & $\pm 0.41^{\mathrm{e}}$ & $\pm 0.15^{\mathrm{de}}$ \\
\hline \multirow[t]{2}{*}{$\mathrm{L}_{2} \mathrm{~T}_{2}$} & $2.2 \times 10^{5}$ & $2.7 \times 10^{5}$ & $3.2 \times 10^{5}$ & $3.5 \times 10^{5}$ & $3.4 \times 10^{5}$ & $3.2 \times 10^{5}$ & $3.1 \times 10^{5}$ \\
\hline & $\pm 0.98^{c}$ & $\pm 0.33^{c d}$ & $\pm 0.65^{\mathrm{d}}$ & $\pm 0.26^{\mathrm{cd}}$ & $\pm 0.45^{\mathrm{d}}$ & $\pm 0.76^{\mathrm{d}}$ & $\pm 0.38 \mathrm{de}$ \\
\hline \multirow[t]{2}{*}{$\mathrm{L}_{2} \mathrm{~T}_{3}$} & $2.0 \times 10^{5}$ & $2.2 \times 10^{5}$ & $2.7 \times 10^{5}$ & $2.9 \times 10^{5}$ & $2.7 \times 10^{5}$ & $2.5 \times 10^{5}$ & $2.2 \times 10^{5}$ \\
\hline & $\pm 0.89^{\mathrm{b}}$ & $\pm 0.77^{\mathrm{b}}$ & $\pm 0.83^{\mathrm{b}}$ & $\pm 0.02^{\mathrm{b}}$ & $\pm 0.07^{\mathrm{b}}$ & $\pm 0.18^{\mathrm{b}}$ & $\pm 0.21^{b}$ \\
\hline
\end{tabular}

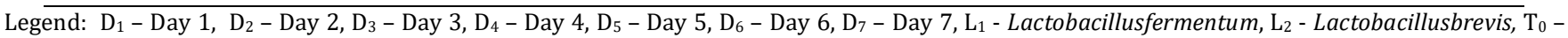
Control; $\mathrm{L}_{1} \mathrm{~T}_{1}-$ L.fermentum $(0.5 \mathrm{~mL}), \mathrm{L}_{1} \mathrm{~T}_{2}-$ L.fermentum $(1.0 \mathrm{~mL}), \mathrm{L}_{1} \mathrm{~T}_{3}-$ L.fermentum $(2.0 \mathrm{~mL}), \mathrm{L}_{2} \mathrm{~T}_{1}-\mathrm{L}_{\text {.brevis }}(0.5 \mathrm{~mL}), \mathrm{L}_{2} \mathrm{~T}_{2}-$ L.brevis $_{2}(1.0 \mathrm{~mL}), \mathrm{L}_{2} \mathrm{~T}_{3}$ - L.brevis $(2.0 \mathrm{~mL})$. Values are given as mean \pm SD. Within columns, values followed by the same alphabets are not significantly different but those followed by different alphabets are significantly different $p \leq 0.05$. 
Table 2. Mean fungal counts (CFU/mL) during storage

\begin{tabular}{llllllll}
\hline \multirow{2}{*}{ Treatment } & \multicolumn{5}{l}{ Storage days } & \multicolumn{5}{l}{} & & \\
\cline { 2 - 7 } & $\mathbf{D}_{\mathbf{1}}$ & $\mathbf{D}_{\mathbf{2}}$ & $\mathbf{D}_{\mathbf{3}}$ & $\mathbf{D}_{\mathbf{4}}$ & $\mathbf{D}_{\mathbf{5}}$ & $\mathbf{D}_{\mathbf{6}}$ & $\mathbf{D}_{\mathbf{7}}$ \\
\hline $\mathrm{T}_{0}$ & $3.5 \times 10^{3}$ & $3.7 \times 10^{3}$ & $4.2 \times 10^{3}$ & $4.7 \times 10^{3}$ & $5.0 \times 10^{3}$ & $5.6 \times 10^{3}$ & $5.9 \times 10^{3}$ \\
& $\pm 0.65^{\mathrm{e}}$ & $\pm 0.15^{\mathrm{f}}$ & $\pm 0.02^{\mathrm{f}}$ & $\pm 0.32^{\mathrm{f}}$ & $\pm 0.51^{\mathrm{e}}$ & $\pm 0.44^{\mathrm{f}}$ & $\pm 0.88^{\mathrm{g}}$ \\
$\mathrm{L}_{1} \mathrm{~T}_{1}$ & $2.9 \times 10^{3}$ & $3.1 \times 10^{3}$ & $3.4 \times 10^{3}$ & $3.7 \times 10^{3}$ & $4.3 \times 10^{3}$ & $4.8 \times 10^{3}$ & $5.2 \times 10^{3}$ \\
& $\pm 0.99^{\mathrm{d}}$ & $\pm 0.87^{\mathrm{d}}$ & $\pm 0.76^{\mathrm{e}}$ & $\pm 0.54^{\mathrm{d}}$ & $\pm 0.34^{\mathrm{d}}$ & $\pm 0.08^{\mathrm{e}}$ & $\pm 0.03^{\mathrm{e}}$ \\
$\mathrm{L}_{1} \mathrm{~T}_{2}$ & $2.1 \times 10^{3}$ & $2.4 \times 10^{3}$ & $2.7 \times 10^{3}$ & $3.0 \times 10^{3}$ & $3.4 \times 10^{3}$ & $3.9 \times 10^{3}$ & $4.3 \times 10^{3}$ \\
& $\pm 0.07^{\mathrm{c}}$ & $\pm 0.19^{\mathrm{c}}$ & $\pm 0.66^{\mathrm{c}}$ & $\pm 0.22^{\mathrm{c}}$ & $\pm 0.11^{\mathrm{c}}$ & $\pm 0.05^{\mathrm{c}}$ & $\pm 0.76^{\mathrm{c}}$ \\
$\mathrm{L}_{1} \mathrm{~T}_{3}$ & $0.9 \times 10^{3}$ & $1.0 \times 10^{3}$ & $1.2 \times 10^{3}$ & $1.3 \times 10^{3}$ & $1.5 \times 10^{3}$ & $1.8 \times 10^{3}$ & $2.0 \times 10^{3}$ \\
& $\pm 0.90^{\mathrm{a}}$ & $\pm 0.34^{\mathrm{a}}$ & $\pm 0.49^{\mathrm{a}}$ & $\pm 0.58^{\mathrm{a}}$ & $\pm 0.60^{\mathrm{a}}$ & $\pm 0.06^{\mathrm{a}}$ & $\pm 0.02^{\mathrm{a}}$ \\
$\mathrm{L}_{2} \mathrm{~T}_{1}$ & $2.9 \times 10^{3}$ & $3.2 \times 10^{3}$ & $3.4 \times 10^{3}$ & $3.8 \times 10^{3}$ & $4.3 \times 10^{3}$ & $4.8 \times 10^{3}$ & $5.3 \times 10^{3}$ \\
& $\pm 0.08^{\mathrm{d}}$ & $\pm 0.10^{\mathrm{de}}$ & $\pm 0.43^{\mathrm{e}}$ & $\pm 0.55^{\mathrm{de}}$ & $\pm 0.97^{\mathrm{d}}$ & $\pm 0.56^{\mathrm{d}}$ & $\pm 0.07^{\mathrm{ef}}$ \\
$\mathrm{L}_{2} \mathrm{~T}_{2}$ & $2.1 \times 10^{3}$ & $2.4 \times 10^{3}$ & $2.8 \times 10^{3}$ & $3.0 \times 10^{3}$ & $3.4 \times 10^{3}$ & $3.9 \times 10^{3}$ & $4.4 \times 10^{3}$ \\
& $\pm 0.08^{\mathrm{c}}$ & $\pm 0.03^{\mathrm{c}}$ & $\pm 0.05^{\mathrm{cd}}$ & $\pm 0.41^{\mathrm{c}}$ & $\pm 0.05^{\mathrm{c}}$ & $\pm 0.31^{\mathrm{c}}$ & $\pm 0.54^{\mathrm{cd}}$ \\
$\mathrm{L}_{2} \mathrm{~T}_{3}$ & $1.0 \times 10^{3}$ & $1.1 \times 10^{3}$ & $1.3 \times 10^{3}$ & $1.5 \times 10^{3}$ & $1.8 \times 10^{3}$ & $2.1 \times 10^{3}$ & $2.3 \times 10^{3}$ \\
& $\pm 0.23^{\mathrm{ab}}$ & $\pm 0.45^{\mathrm{ab}}$ & $\pm 0.88^{\mathrm{ab}}$ & $\pm 0.09^{\mathrm{b}}$ & $\pm 0.05^{\mathrm{b}}$ & $\pm 0.16^{\mathrm{b}}$ & $\pm 0.06^{\mathrm{b}}$
\end{tabular}

Legend: $\mathrm{D}_{1}$ - Day 1, $\mathrm{D}_{2}$ - Day 2, $\mathrm{D}_{3}$ - Day 3, $\mathrm{D}_{4}$ - Day 4, $\mathrm{D}_{5}-$ Day 5, $\mathrm{D}_{6}$ - Day 6, $\mathrm{D}_{7}-$ Day 7, $\mathrm{L}_{1}-$ Lactobacillusfermentum, $\mathrm{L}_{2}-$ Lactobacillusbrevis, $\mathrm{T}_{0}-$ Control; $\mathrm{L}_{1} \mathrm{~T}_{1}-$ L.fermentum (0.5mL), $\mathrm{L}_{1} \mathrm{~T}_{2}-$ L.fermentum (1.0mL), $\mathrm{L}_{1} \mathrm{~T}_{3}-$ L.fermentum $(2.0 \mathrm{~mL}), \mathrm{L}_{2} \mathrm{~T}_{1}-$ L.brevis $(0.5 \mathrm{~mL}), \mathrm{L}_{2} \mathrm{~T}_{2}-L_{\text {. }}$ brevis $(1.0 \mathrm{~mL}), \mathrm{L}_{2} \mathrm{~T}_{3}$ - L.brevis $(2.0 \mathrm{~mL})$. Values are given as mean \pm SD. Within columns, values followed by the same alphabets are not significantly different but those followed by different alphabets are significantly different $p \leq 0.05$.

Table 3 shows the mean scores of the sensory evaluation for all the juice samples, which was carried out on the fourth day (considered as the peak of the preservation). There were observable changes in the sensory parameters (appearance, flavour, taste and texture) of the stored juice and the changes increased with time and level of concentration. The treated juice sample of $\mathrm{L}_{1} \mathrm{~T}_{3}$ had the best general acceptability score (8.5) followed by $\mathrm{L}_{2} \mathrm{~T}_{3}(6.0)$ ). Values obtained were statistically significant when compared $(\mathrm{p}<0.05)$.

Table 3. Mean scores of sensory evaluation of the watermelon juice on day 4

\begin{tabular}{llllll}
\hline Sample & Appearance & Flavour & Taste & Texture & General acceptability \\
\hline $\mathrm{T}_{0}$ & $3.5 \pm 0.04^{\mathrm{d}}$ & $1.3 \pm 0.45^{\mathrm{d}}$ & $\mathrm{NA}$ & $\mathrm{NA}$ & $2.3 \pm 0.67^{\mathrm{f}}$ \\
$\mathrm{L}_{1} \mathrm{~T}_{1}$ & $3.4 \pm 0.22^{\mathrm{d}}$ & $4.0 \pm 0.12^{\mathrm{b}}$ & $1.5 \pm 0.29^{\mathrm{e}}$ & $1.7 \pm 0.05^{\mathrm{c}}$ & $3.4 \pm 0.30^{\mathrm{e}}$ \\
$\mathrm{L}_{1} \mathrm{~T}_{2}$ & $5.2 \pm 0.65^{\mathrm{ab}}$ & $4.2 \pm 0.20^{\mathrm{ab}}$ & $4.4 \pm 0.18^{\mathrm{c}}$ & $4.2 \pm 0.18^{\mathrm{ab}}$ & $4.1 \pm 0.45^{\mathrm{cd}}$ \\
$\mathrm{L}_{1} \mathrm{~T}_{3}$ & $5.5 \pm 0.09^{\mathrm{a}}$ & $4.3 \pm 0.34^{\mathrm{a}}$ & $5.3 \pm 0.45^{\mathrm{a}}$ & $4.5 \pm 0.15^{\mathrm{a}}$ & $8.5 \pm 0.36^{\mathrm{a}}$ \\
$\mathrm{L}_{2} \mathrm{~T}_{1}$ & $3.4 \pm 0.18^{\mathrm{a}}$ & $1.1 \pm 0.08^{\mathrm{e}}$ & $1.4 \pm 0.56^{\mathrm{e}}$ & $1.4 \pm 0.22^{\mathrm{cd}}$ & $3.2 \pm 0.08^{\mathrm{e}}$ \\
$\mathrm{L}_{2} \mathrm{~T}_{2}$ & $4.1 \pm 0.32^{\mathrm{c}}$ & $3.9 \pm 0.33^{\mathrm{c}}$ & $4.1 \pm 0.44^{\mathrm{cd}}$ & $4.0 \pm 0.19^{\mathrm{ab}}$ & $4.3 \pm 0.15^{\mathrm{c}}$ \\
$\mathrm{L}_{2} \mathrm{~T}_{3}$ & $5.1 \pm 0.30^{\mathrm{ab}}$ & $4.2 \pm 0.40^{\mathrm{ab}}$ & $5.2 \pm 0.34^{\mathrm{ab}}$ & $4.1 \pm 0.67^{\mathrm{ab}}$ & $6.0 \pm 0.40^{\mathrm{b}}$
\end{tabular}

Legend: $\mathrm{L}_{1}-$ Lactobacillus fermentum, $\mathrm{L}_{2}-$ Lactobacillus brevis; $\mathrm{T}_{0}-$ Control; $\mathrm{L}_{1} \mathrm{~T}_{1}-$ L. fermentum $(0.5 \mathrm{~mL}) ; \mathrm{L}_{1} \mathrm{~T}_{2}-$ L. fermentum $(1.0 \mathrm{~mL}) ; \mathrm{L}_{1} \mathrm{~T}_{3}-$ L. fermentum $(2.0 \mathrm{~mL}) ; \mathrm{L}_{2} \mathrm{~T}_{1}-$ L. brevis $(0.5 \mathrm{~mL}) ; \mathrm{L}_{2} \mathrm{~T}_{2}-$ L.brevis $(1.0 \mathrm{~mL}) ; \mathrm{L}_{2} \mathrm{~T}_{3}-$ L.brevis $(2.0 \mathrm{~mL})$; NA - Not applicable. Values are given as mean $\pm \mathrm{SD}$. Within columns, values followed by the same alphabets are not significantly different but those followed by different alphabets are significantly different $p \leq 0.05$.

\section{Discussion}

The $\mathrm{pH}$ of untreated watermelon juice $\left(\mathrm{T}_{0}\right)$ followed an increasing trend as the storage period advanced, while the acidity of untreated juice decreased as the storage period advanced. The decrease in the acidity of the untreated watermelon juice could be attributed to the non-treatment of the juice sample with LAB. In addition, high pH value of the control (untreated) samples could be due to the superficial development of molds which lead to the loss of 
Ike et al. / GSC Biological and Pharmaceutical Sciences, 2020, 10(03), 126-136

acidification and deaminase activities as also reported by [21;22]. The result obtained is in agreement with the reports of $[23 ; 24]$.

The $\mathrm{pH}$ of treated juice samples significantly decreased as the day progressed $(\mathrm{p}<0.05)$. The values of $\mathrm{pH}$ for the treated sample were lower compared to the control sample $\left\{\mathrm{T}_{0}\right)$. $\mathrm{L}_{1} \mathrm{~T}_{3}$ sample had the lowest $\mathrm{pH}(3.3 \pm 0.33)$ followed by $\mathrm{L}_{2} \mathrm{~T}_{3}$ sample $(3.8 \pm 0.19)$ at $\mathrm{D}_{7}$. Thus, storage period had a significant decreasing effect on the $\mathrm{pH}$ of the stored treated watermelon juices. A decline in $\mathrm{pH}$ during storage as observed may be due to accumulation of organic acids as confirmed by the strong acidifying activity of LAB [24]. The reduction in $\mathrm{pH}$ could be traced to action of citric acid and ascorbic acid on the sugar and protein component of the product. Production of lactic acid, organic acids and amino acids by the isolates also led to an increase in acidity and a decrease in $\mathrm{pH}$. Lactose and proteins are converted into lactic acid and amino acids leading to increase in acidity and decrease in $\mathrm{pH}$ of beverages [25].The lower $\mathrm{pH}$ value of the juice certainly increases the storage stability of the stored product by impeding growth of undesirable microorganism including coliforms [26]. Food acids dictate the dominant microflora in foods and to a large extent will determine the shelf stability of the juice. The more acidic the juice, the less susceptible to bacterial action but the more susceptible to the action of yeasts and moulds [27].Most bacteria will not grow at low $\mathrm{pH}$ [28] and hence improves the storage quality and shelf life of the stored watermelon juice. Lactic acid bacteria are known to produce antimicrobial substances mainly in the form of organic acids and other metabolites [29;30]. The reduction in $\mathrm{pH}$ within the period of study is accepted because juice spoilage is mainly by yeast fermentation which is also evident in higher tendencies toward acidity, and this agrees with the report of [31]. The decreases in $\mathrm{pH}$ as recorded in the results obtained are in conformity with the findings of [32] in the experiment with whey-based orange beverage. [33] in LAB fermented cashew apple juice, [34] in cantaloupe juice,and [35] in the whey based watermelon beverage. [36] reported that conversion of sugar into organic acids during fermentation resulted in decreased $\mathrm{pH}$ in litchi juice fermented by Lactobacillus acidophilus, Lactobacillus plantarum and Lactobacillus rhamnosus

The total titratable acidity of treated-stored watermelon juice samples was significantly $(\mathrm{p}<0.05)$ higher than that of untreated-stored watermelon juice sample $\left(\mathrm{T}_{0}\right)$. The titratable acidity increased gradually with storage time in the treated watermelon juice samples. Hence, $\mathrm{pH}$ and acidity are two important factors that are co-related to each other. The changes in the titrable acidity during storage are affected by recipe and treatment combinations. The decrease in $\mathrm{pH}$ during the storage of the samples could also have contributed to high titratable acidity recorded in this study. The decrease in $\mathrm{pH}$ of stored watermelon juice samples could enhance the obtained acidity during storage. It was also observed that storage of watermelon juice samples led to the reduction of the $\mathrm{pH}$ and increase in titratable acidity of samples. The observed increase in titratable acidity and decrease in $\mathrm{pH}$ could be due to the dominance of the environment by lactic acid bacteria which degrades carbohydrates resulting in acidification; and accumulation of organic acids by strong acidifying activity of LAB [24]. These observations were in agreement with earlier studies by [37] who stated that the increase in titratable acidity of millet-soya bean blends and decrease in $\mathrm{pH}$ of millet-soya bean blends was as a result of the presence of lactic acid bacteria that degrades the carbohydrates. Also in agreement was the work of [24].

It was observed that the total solid (TS) contents of the stored watermelon juice samples decreased significantly $(\mathrm{p}<0.05)$ as the storage time increased. The decrease in TS could be due to the utilization of sugars by fermenting organisms during storage, leading to degradation of sugars. The result obtained in this study is in conformity with the reports of [38] when he studied microbiological and some sensory attributes of watermelon juice and watermelonorange juice mix.

Sugar content of the stored watermelon juice samples also decreased significantly $(\mathrm{p}<0.05)$ as the storage time increased. The $\mathrm{pH}$ range of watermelons juice according to [28] is 5.2-5.6. This is an aciduric environment that supported the growth ability and activities of yeast and moulds and discouraged growth of the bacterial flora. This resulted in the evidenced fermentation activities during storage leading to reductions in total solids and sugar contents as storage time progressed. This reduced $\mathrm{pH}$ value among watermelon juice as reported by [28] is accepted because juice spoilage is mainly by yeast fermentation which is also evident in their tendencies towards acidity. The observed increase in titratable acidity and decrease in $\mathrm{pH}$ could be due to the dominance of the environment by lactic acid bacteria and yeast which degrades carbohydrates resulting in acidification. The results obtained in this study are in conformity with the reports of [37] and [38].

The effect of different treatment concentrations on the microbial counts of the watermelon juice samples showed that $\mathrm{T}_{0}, \mathrm{~L}_{1} \mathrm{~T}_{1}$ and $\mathrm{L}_{2} \mathrm{~T}_{1}$ had highest bacterial loads at $\mathrm{D}_{4}$ before the progressive decrease. This showed that the $\mathrm{D}_{4}$ was the peak of fermentation for the stored juice. There was no decline in fungal counts at $\mathrm{D}_{4}$ as was recorded in the case of bacterial count. This was traced to the aciduric environment of watermelon juice samples as was reported by [28] which influenced the increase in titratable acidity and decrease in $\mathrm{pH}$ of the stored juice sample that made growth of bacterial 
flora susceptible and supported growth activities of yeast and moulds. Hence, most juice spoilage microorganism are yeast and mold. There is a clear correlation between treatment concentrations and microbial loads as the higher the treatment concentration, the lower the microbial load. This was evidently observed in the results obtained with $\mathrm{L}_{1} \mathrm{~T}_{3}$ and $\mathrm{L}_{2} \mathrm{~T}_{3}$ samples of the stored watermelon juice as it recorded the least bacterial and fungal counts during storage. This had suggested that the higher the treatment concentration, the more effective the preservation of the stored juice. The decrease in the bacterial load could be due to the decrease in the $\mathrm{pH}$ of the juice as most bacteria do not grow at low $\mathrm{pH}$, while that of fungi could be due to deposited antimicrobials.

The sensory evaluation carried out on the fourth day, which was considered as the peak of the preservation had significant values $(\mathrm{p}<0.05)$. These observable changes in the sensory parameters (appearance, flavour, taste and texture) of the juice, increased with time. The changes in the sensory parameters were affected by the level of concentration. Sensory studies carried out to ascertain the treated watermelon juice with the best quality in sensory profile comprised a panel of 10 trained judges based on 9 point Hedonic scale. The highest general acceptability score for all attributes was given to the juice sample $\mathrm{L}_{1} \mathrm{~T}_{3}(8.5 \pm 0.36)$.

\section{Conclusion}

The results of this study revealed that the concentration of bio-preservative (Lactobacillus species) affects the microbial load, nature, organoleptic and sensory properties of the juice during storage. This method had proved efficient in reducing microbial count and in retaining nutrient quality of the juice, since soluble solids and total sugar content were not affected significantly. The utilization of the bio-preserved juice should be encouraged and recommended to people with vitamin $C$ deficiency because of its high content in vitamin C. Finally, bio-preservation of watermelon juice is important because of the seasonality of its fruit, which makes it scarce and abundant at different seasons.

\section{Compliance with ethical standards}

\section{Acknowledgments}

The authors are grateful to all contributors for their commitment.

\section{Disclosure of conflict of interest}

No conflict of interest.

\section{References}

[1] Baker TP, Corwin B and Jett LW.(2012).Watermelon bacterial fruit blotch. Journal of Fruit Ornament Plant Resources, 18, 231-232.

[2] Erukainure OL, Oke OV, Daramola AO, Adenekan SO and Umanhonlen EE. (2010).Improvement of the biochemical properties of watermelon rinds subjectedto Saccharomyces cerevisae solid media fermentation. Journal of Nutrition Pakistan,9, 806-809.

[3] Mossel DAA, Corey JEL, Struikj CB and Baird RM. (1995). Essentials of the Microbiology of Foods. A text book for advanced studies. John and Wiley and Sons, New York, USA.

[4] Bello 00, Bello TK, Fashola MO and Oluwadun A. (2014). Microbiological quality of some locally-produced fruit juices in Ogun State, South Western Nigeria. E3 Journal of Microbiology. Resources, 2, 1-8.

[5] OlubukolaOB, ObasholaEF and RamokoniEG. (2011). Microbiological quality control study of some processed fruit juices by conventional approach. Life Science Journal, 8, 18-24.

[6] Anon S. (2006). Nasarawa State Agricultural Development Programme. Annual Crop Area and Yield Survey, Lafia, Nasarawa State.

[7] Block G, Vitamin C and cancer prevention: the epidemiological evidence. Am J Clin Nutr. (1991). 53, 270S-282S.

[8] Rani L, Sharma N,Singh Sand Grewal SA. (2019) Therapeutic Potential of Vitamin C: An Overview of Various Biological Activities. International Journal of Pharmaceutical Quality Assurance, 10(4), 605-612.

[9] Caplice E and Fritzegerald GF. (1999). Food Fermentation: Role of Microorganisms in food production and preservation. International Journal of Food Microbiology, 50, 131 - 149. 
[10] Messens W and De Vugst L. (2002). Inhibitorysubstances produced by Lactoacilli isolated fromsourdougts- A review. International Journal of foodMicrobiology, 72, 31-43.

[11] Dalié DKD, Deschamps AM and Richard Forget F. (2009). Lactic acid bacteria - Potential forcontrol of mould growth and mycotoxins. A review.Food Control, 21, 370-380.

[12] Ström K, Sjörgen J, Broberg A and Schnürer J. (2002). Lactobacillus plantarum MiLAB 393 produces theantifungal cyclic dipeptides cyclo(L-Phe-L-Pro) andcyclo(L-Phe-trans-4-OH-L-Pro) and 3 phenyllactic acid.Applied and Environment Microbiology, 68, 4322-4327.

[13] Ananou S, Maqueda M, Martinez-Bueno M and Valdivia E. (2007). Biopreservation an ecological approach to improve the safety and shelf-life of food. Communicating Current Research and Educational Topics and Trends in Applied Microbiology,475-490.

[14] Nath S, Supratim C and Dora KC. (2014).Role of biopreservation in improving food safety. Journal of Engineering Research,4(1), 26-32.

[15] de Man, JC Rogosa, M and Sharpe ME. (1960). A medium for the cultivation ofLactobacilli. Journal of Applied Bacteriology, 23, 130-135.

[16] Cappucino GJR and Sherman B. (2010). Microbiology: A Laboratory Manual, Nineth Edition. The Benjamin Publishing Coy. California.

[17] Boone DR, Castenholz RW, Garrity GM, Brenner DJ, Krieg NR and Staley JR (Eds.). (2005). Bergey's Manual of Systematic Bacteriology. Second Edition. New York: SpringerVerlag.

[18] Hammes WP and Hertel C. (2006). The genera Lactobacillus andCarnobacterium. In: The Prokaryotes, $3^{\text {rd }}$ edition. (Eds: Dworkin M, Falkow S, Rosenberg E, Schleifer KH. and Stackebrandt E.) NewYork, Springer, 4, 320-403.

[19] Gwana AM, Bako MM, Bagudu BY, Sadiq AB and Abdullahi MM. (2014). Determination of phytochemical, vitamin, mineral, and proximate compositions of varieties of watermelon seeds cultivated in Borno State, North-Eastern Nigeria. International Journal of Nutrition and Food Sciences, 3(4), 238-245.

[20] AOAC. (2007). Official methods of analysis. (18 th ed.) Association of Official Analytical Chemists; Washington, DC.

[21] Marchesini B, Bruttin A, Romailler N, Moreton RS, Stuc-chi C and Sozzi T. (1992). "Microbiological events during commercialmeat fermentations,"Journal of Applied Bacteriology,73(3), 203-209.

[22] Sunesen LO and Stahnke LH. (2003). "Mould starter cultures for drysausages-selection, application and effects,"Meat Science, 65(3), 935-948.

[23] Shubhada N, Rudresh DL, Jagadeesh SL, Prakash DP and Raghavendra S. (2018). Fermentation of Pomegranate Juice by Lactic Acid Bacteria. International Journal of Current Microbiology and Applied Sciences,7(08), 41604173.

[24] Aissé B, Helena A, Joana BB, Imene F, Yosra G, Afef N, Abdellatif B, Paula T and Hadda-Imene 0. (2019). Inhibitory Effect of Lactobacillus plantarum FL75 and Leuconostoc mesenteroides FL14 against Foodborne Pathogens in Artificially Contaminated Fermented Tomato Juices. Hindawi BioMed Research International,1-12.

[25] Jaspreet K, Dhillon B and Puri S. (2015). Development of health based functional whey drink incorporating carrot, beetroot, mint and ginger. Beverage and Food World, 42(4), 41-44.

[26] Uzeh RE, Alade FA and Bankole M. (2009). The microbial quality of pre packed mixed vegetables salad in some retail outlets in Lagos, Nigeria. African Journal of Food Science, 3(9), 270-272.

[27] Ndife J, Awogbenja D and Zakari U. (2013). Comparative evaluation of the nutritional and sensory quality of different brands of orange-juice in Nigerian market. African Journal of Food Sciences,7, 479-484.

[28] Jay MJ, Loessner MJ and Golden DA. (2005).Modern Food Microbiology, Seventh Edition. Springer Publishers, USA, 40-58.

[29] Tserovska L, Stefanova S and Yordanova T. (2002). Identification of lactic acid bacteria isolated from Katyk, goats milk and Cheese. Journal of Culture Collection, 3, 48-52.

[30] Obadina AO, Oyewole OB, Sanni LO and Tomlins KI. (2006).Bio-preservative activities of Lactobacillus plantarum strains in fermenting Casssava "fufu".African Journal of Biotechnology, 5, 620-623.

[31] Frazier WC and Westhoff DC. (1988).Food Microbiology. 4th Edn., McGraw Hill, New Delhi, India, ISBN-13: 9780070667181, 83-98. 
[32] Das S, Chatterjee G, Neve DJ and Dutta A. (2015). Formulation and statistical evaluation of a ready to drink whey based orange beverage and its storage stability. Revista Mexicana de Ingenieria Quimica, 14(2), 253-264.

[33] Pereira ALF, Maciel TC and Rodrigues S. (2011). Probiotic beverage from cashew apple juice fermented with Lactobacillus casei. Food Resources International, 44, 1276-1283.

[34] Fonteles TV, Costa MGM, Ana Jesus LTD and Rodrigues S. (2011).Optimization of the fermentation of cantaloupe juice by Lactobacillus casei NRRL B-442. Food Bioprocess Technology, 455-760.

[35] Naik YK, Khare A, Choudhary PL, Goel BK and Shrivastava A. (2009). Studies on physicochemical and sensory characteristics of whey based watermelon beverage. Asian Journal of Research in Chemistry, 2, 57-59.

[36] Kalita D, Mandal M and Mahanta CL. (2015). Characterisation of litchi juice fermented by probiotic lactic acid bacteria. International Journal of Food Nutrition Science, 4(4), 23-31.

[37] Ojokoh AO and Babatunde B. (2014). Effect of fermentation on nutrient and antinutrient composition of millet (Pennisetum glaucum) and soyabean (Glycine max) blend flours. Journal of Life Sciences, 8, 668-675.

[38] Ijah UJJ, Ayodele HS and Aransiola SA. (2015). Microbiological and Some Sensory Attributes of Water Melon Juice and Watermelon-orange Juice Mix.Journal of Food Resource Science, 4(3), 49-61.

\section{How to cite this article}

Ike CC, Ogwuegbu HO and Akwari DK. (2020). Bio-preservation of processed watermelon (Citrullus lanatus) juice using Lactobacillus species isolated from processed fermented maize (akamu). GSC Biological and Pharmaceutical Sciences, $10(3), 126-136$. 